\title{
Should librarians and information professionals be content with current UK copyright law?
}

\author{
David Gee *
}

These days it almost seems a rule of thumb that whenever two or more librarians are gathered together there will be some grumbling about UK copyright law and the legal restrictions it places on librarians and their users on copying from published books and electronic databases. In reality, should we be so discontented, or does current UK copyright law provide an objective balance between the protective and commercial concerns of rights owners such as authors and publishers on the one hand and the research and professional needs of librarians and our users on the other? To answer this question, this article will seek to provide an overview of the current copyright position within the UK from the perspective of both the rightsowners and librarians. Although some of the current copyright regime does seem fair and in balance, a number of worrying issues for librarians and their users relating to digital copyright will become apparent from this overview which I would suggest need to be resolved by changes to the law in order to provide a better balance.

\section{Overview of current UK copyright law}

I will begin my overview of current UK copyright law by examining the copyright regime set up by the UK Copyright, Designs and Patents Act of 1988. I will then assess the impact of several key EU Directives and implementing UK Statutory Instruments on the working of this regime, and in particular discuss the implications of the new rights for owners of digital material.

\section{Copyright, Designs and Patents Act, 1988}

This key UK copyright act took effect from August 1989 and gave legal rights to authors, dramatists, composers and artists who create original literary, dramatic, musical and artistic works. It also gave rights to publishers who create the typographical arrangements of published editions of works, and it gave rights to creators of sound recordings, films and broadcasts. These statutory rights fall into two broad groups.

\section{Statutory rights to control use}

Firstly, the Act and subsequent Statutory Instruments gave these creators economic rights to control the use of their works. Copyright owners have the right to authorise or prohibit the copying of their work in any way (including the storing of their work electronically), the renting, lending or publishing of their work, the performing, broadcasting or showing of their work (including the electronic transmission of their work over the web) and the adaptation or translation of their work. It makes no

\footnotetext{
* David Gee, BA, MA, DipLib, MCLIP has more than twenty years experience working in academic libraries and legal information management and is currently Deputy Librarian \& Academic Services Manager at the Institute of Advanced Legal Studies in the University of London. He has been a member of the BIALL Council, a senior member of the Editorial Board of Legal Information Management for many years and has written a number of articles for UK and international professional journals. For the past five years he has been a member of the CPD25 Steering Group and Chair of the CPD25 Career Development Group. CPD25 is the training arm of the M25 Consortium of Higher Education Libraries in the London Area (http://www.cpd25.ac.uk).
} 
difference in law whether their work is in print or in digital format, so email and material on websites and blogs are protected as well.

The second group of statutory rights introduced by the 1988 Act are called moral rights. For example, authors have the right to be identified as the author of their work and can object to the derogatory treatment of their work and the false attribution of works which they did not write.

It is important to point out that copyright is an automatic statutory right. Creators do not need to register their works or even use the copyright symbol in order to be accorded these legal rights. It is essential, though, that the work is original and not a copy of another work. Ideas do not qualify. Copyright only subsists in the form in which ideas are expressed.

\section{Duration of UK copyright protection}

The 1988 Act and subsequent amending Statutory Instruments have resulted in the following current positions:

i) For a literary, dramatic, musical or artistic work, copyright normally expires 70 years from the end of the year in which the last remaining known author of the work dies.

ii) For the typographical arrangement, copyright expires 25 years from the end of the year of first publication.

iii) For sound recordings (e.g. tapes and CDs), copyright expires 50 years from the end of the year in which the work was created, or if the work is released to the public in that time the copyright expires 50 years from the end of the year in which the work is released to the public.

iv) For films, copyright expires 70 years from the end of the year in which the last principal director, screenplay author, dialogue author or composer dies.

v) For broadcasts and also (explicitly since a 2003 UK Statutory Instrument ${ }^{1}$ ) for any communication to the public by electronic transmission (e.g. over the web), copyright expires 50 years from the end of the year in which the broadcast or electronic communication is first made.

\section{Statutory permissions to copy}

As well as protecting the creators of original works, UK copyright law also seeks to find a balance between the legitimate economic and moral rights of creators of works and the needs of users to have access and some use of such works in order to pursue new research and expand human knowledge. For many years commentators working in education have put the latter case to government and strongly argued that research and educational purposes are valid reasons for limited copying exceptions. In general, however, successive UK governments have always tried to ensure when enacting an exception to authors' rights that the legitimate economic and moral interests of copyright owners to exploit their works are not unduly prejudiced. This is known as the "copyright balance" and is required under international conventions such as the Berne Convention to which the UK is a signatory. ${ }^{2}$

\footnotetext{
${ }^{1}$ Broader right explicitly contained in the Copyright and Related Rights Regulations, 2003 (SI 2003/2498). The full text of the Regulations can be found on the OPSI website at: http://www.opsi.gov.uk/legislation/about_legislation.htm.

${ }^{2}$ See Article 9(2) of the Berne Convention (last revised in 1979). Full convention available on the WIPO website at http://www.wipo.int/treaties/en/ip/berne/trtdocs_wo001.html.
} 
The Copyright, Designs and Patents Act, 1988 contained a number of statutory "permission to copy" exceptions that it is argued do not infringe the rights of copyright owners. In particular I would like to examine the following four key exceptions for librarians: fair dealing, the parliamentary and judicial proceedings exceptions, the copying by librarians in prescribed libraries exception, and the copying by (and for) visually-impaired persons exception.

\section{a) Fair dealing copying exception}

The phrase "fair dealing" is not defined as such in the 1988 Act and is therefore not a legal "right" which guarantees immunity against legal action for copyright infringement. However, it is generally assumed to be a legal "defence" which can be called upon when faced with accusations of copyright infringement. In terms of purpose the Act was more specific and permitted limited copying from a published literary, dramatic, musical or artistic work for the purposes of research or private study. The Act did not define specific limits on the amount of copying allowed, but stated that a person could not copy a "substantial" amount from a published copyright-protected work as this would infringe the interests of the copyright owner. The legislation relating to copying for the purposes of research and private study applies to literary, dramatic, musical and artistic works. It does not extend to sound recordings, films, broadcasts or typographical arrangements. The single copy made for the purposes of research or private study should be acknowledged as long as this is practical.

As there are no exact statutory copying limits contained in the Act or successive legislation, UK librarians have had to rely on guidelines published by the Chartered Institute of Library and Informational Professionals ${ }^{3}$. CILIP currently recommends:

- One chapter from a book or extracts amounting to a maximum of $5 \%$ (whichever is the greater)

- One article from an issue of a journal or extracts amounting to a maximum of $5 \%$ (whichever is the greater)

- One law report from a volume of law reports or extracts amounting to a maximum of $5 \%$ (whichever is the greater)

\section{Impact of SI 2003/2498 on fair dealing}

The fair dealing copying exceptions permitted in the 1988 Act were restricted by the Copyright and Related Rights Regulations, 2003 (SI 2003/2498) which were passed in part to implement the EU Directive 2001/29/EC (this EU copyright directive sought to harmonise copyright legislation across the EU). This 2003 SI explicitly banned fair dealing copying for research that is undertaken for a commercial purpose and made it clear that private study must not be for a commercial advantage. As a direct consequence, fair dealing copying is now only permitted for research that is undertaken for a non-commercial purpose or for private study. This key change in the law was very controversial and was strongly lobbied against by CILIP, but to no avail.

Furthermore, the $2003 \mathrm{SI}$ did not give a comprehensive statutory definition of "commercial purpose". This leaves UK librarians with the continuing problem of trying to give clear advice to their users when they ask what is (and what is not) "commercial purpose" when copying for research or private study. In general, because of the threat of being sued for giving inaccurate advice, CILIP guidelines tell

\footnotetext{
${ }^{3}$ For more details about the role of CILIP see www.cilip.org.uk.
} 
UK librarians to err on the side of caution and to leave it to the user to make the final decision.

\section{b) Parliamentary and judicial proceedings copying exception}

The second important statutory "permission to copy" exception concerns copying for parliamentary and judicial proceedings. This exception is permitted under section 45 of the 1988 Act and its scope has not been restricted by the "commercial purpose" rule contained in the controversial $2003 \mathrm{SI}$. Essentially the law says that copyright is not infringed by copying for the purposes of parliamentary or judicial proceedings. The term "parliamentary proceedings" is now defined as including proceedings of the UK Parliament, Scottish Parliament, Northern Ireland Assembly and the European Parliament. The term "judicial proceedings" is defined as including "proceedings before any court, tribunal or person having authority to decide any matter affecting a person's legal rights or liabilities". ${ }^{4}$ Although there is nothing specific in the Act, copying under judicial proceedings is generally assumed to refer to any copying made after the issue of a writ (i.e. after legal proceedings have began). Librarians may be asked to copy material for this purpose - and this is perfectly acceptable. There are no legal requirements to ask the requester to sign a declaration form. However in practice librarians may ask the requester to do so in order to have written confirmation.

\section{c) Copying by librarians in prescribed libraries exception}

The third exception concerns copying by librarians for their users and for fulfilling British Library inter-library loans requests. Library copying is governed by the library regulations or library privilege contained in the 1988 Act and subsequent 1989 Statutory Instrument. ${ }^{5}$ The legislation only applies to librarians working in what are defined as "prescribed" or "not for profit" libraries such as university and college libraries funded by government grants, government department libraries and public and school libraries funded by local government grants. The requester has to sign a declaration to say that a copy of the material has not been supplied to them before and that someone with whom they work or study has not requested the same material before. In addition since the $2003 \mathrm{SI}$ came into force, the requestor has also to declare that the material to be copied is either for non-commercial research purposes or for private study. ${ }^{6}$ The legislation relating to copying by librarians in prescribed libraries applies to literary, dramatic and musical works. It does not currently extend to copying artistic works, sound recordings, films and broadcasts. The limits on copying by librarians are a little more defined in the legislation (i.e. one article from any one issue of a periodical or a "reasonable" part of a monographic work), but in practice very similar to the "fair dealing" guidelines outlined earlier. Finally prescribed libraries must charge a fee to cover the costs of making the copy, without making a profit.

\section{d) Copying by (and for) visually-impaired persons exception}

The fourth statutory "permission to copy" exception concerns copying by (and for) visually impaired persons. The 1988 Act did not contain any specific exceptions to allow copying in alternative formats by, or for, blind or partially sighted persons who cannot read very easily. Following on from pressure from the Royal National Institute for the Blind and CILIP, the Copyright (Visually Impaired Persons) Act 2002 was passed and became law on $31^{\text {st }}$ October 2003. The Act introduced two new copying exceptions for visually impaired persons, subject to strict conditions. The first

\footnotetext{
${ }^{4}$ Definition contained in Section 178 of the Copyright, Designs and Patents Act, 1988.

${ }^{5}$ Copyright (Librarians and Archivists) (Copying of Copyright Material) Regulations, 1989 (SI 1989/1212).

${ }^{6}$ Copyright and Related Rights Regulations, 2003 (SI 2003/2498).
} 
exception was that a visually impaired person (or somebody else on their behalf) could make a single accessible format copy of a complete work for personal use, and the second was that certain designated bodies could make multiple accessible format copies of a complete work and supply them to visually impaired persons for their personal use. In both cases an accessible format copy meant that the copy could be in whatever format that will enable a visually impaired person to read it, e.g. in Braille, Moon, audio or large print. Different formats were deliberately not specified in the Act so that there was no future restriction if new ways of providing access were devised. The Act applies to commercially published literary, dramatic, musical and artistic works and published editions. Significantly, however, it does not apply to the copying of whole databases or performances of musical works. Nobody is allowed to profit financially from the process.

i) Accessible format copy for a visually impaired person:

The Act wanted to ensure that a rights owner was not deprived of a sale in the copying process. Consequently in the specific conditions for making an "accessible" copy for an individual visually impaired person it was stated that the required format must not be already available commercially (and if it was this should be purchased rather than a new copy being made), that the person had obtained lawful access to the original (by either purchasing it or accessing it in a library) and that the accessible format copy carried an acknowledgement to this effect and said that the original was "copied under section 31A of the Copyright, Designs and Patents Act 1988".

ii) Multiple copying for visually impaired persons:

The Act stated that only educational establishments or non-commercial bodies as defined in section 174 could make multiple accessible format copies for visually impaired persons and that these designated bodies must be in possession of a master copy. The rights owner should also be notified within a reasonable time that such copies have been made. Accessible format copies must be made for educational purposes and should not be supplied to a visually impaired person who already has access to a commercially available copy in the desired format. All accessible format copies should be acknowledged and should state that they were, "copied under section 31B of the Copyright, Designs and Patent Act 1988". A revised list of categories of educational institutions that can legally make multiply copies for visually impaired persons was included in subsidiary legislation passed in $2005{ }^{7}$

The RNIB website provides a catalogue of over 170,000 items available for loan and/or sale in audio, large and giant print, Braille and Moon. This catalogue has recently incorporated "Revealweb" which used to provide this service independently. The web address is: http://librarycatalogue.rnib.org.uk.

\section{Crown and Parliamentary copyright}

Regulations relating to Crown and Parliamentary copyright were also included in the Copyright, Designs and Patents Act 1988 and have been extended more recently with the creation of the Scottish Parliament, Welsh Assembly and Northern Ireland Assembly.

\section{Crown copyright and "copyright-waived" material}

Material created by employees of the Crown in the course of their duties is protected by Crown copyright. The relevant copyright regulations are defined in section 163 of the 1988 Copyright, Designs and Patents Act. Crown copyright in unpublished

\footnotetext{
${ }^{7}$ See the Copyright (Educational Establishments) Order, 2005 (SI 2005/223).
} 
material expires 125 years from the end of the year in which the work was created. Crown copyright in commercially published material expires 50 years from the end of the year in which it was published. Nevertheless, the copyright in much UK legislative material (e.g. Acts of parliament and Statutory Instruments) is waived as long as the reproductions comply with specific waiver conditions. Other Crown copyright material subject to waiver includes government consultative documents such as Green Papers, government press notices and government forms. Full details of what is currently permitted under Crown copyright and the detailed waiver conditions are available on the Office of Public Sector Information website. ${ }^{8}$

\section{Parliamentary copyright and "copyright-waived" material}

Parliamentary copyright covers any work made, directed or controlled by the House of Commons, House of Lords and Scottish Parliament and subsists for 50 years from the end of the year in which the work was created (there are very similar provisions for the measures of the Northern Ireland and Welsh Assemblies). Bills of Parliament, Explanatory Notes to Bills of the UK Parliament, Lords and Commons Official Reports (Hansard), House business papers (including the Journals of both Houses), the Daily Business Papers (Vote Bundle) and the Commons Public Bill lists and Statutory Instruments lists are the main categories of material that qualify for Parliamentary copyright protection. A Parliamentary copyright waiver covers bills and explanatory notes to bills, and the specific waiver conditions for these documents are explained in "Guidance Note 14", available on the OPSI website. ${ }^{9}$ Guidance on the copying restrictions for all other Parliamentary copyright material are covered by the "Guidance for Librarians" document or so-called "Dear Librarian letter", again available in full-text on the OPSI website. This official guidance is technically not a waiver of Parliamentary copyright, but simply official permission for more generous copying than would normally be allowed under UK legislation.

Having examined the legal rights of copyright owners, outlined the main statutory copying exceptions and discussed the specific regulations relating to Crown and Parliamentary copyright, I now want to summarise the current regime relating to databases and copyright and an associated new right for database makers called "database right".

\section{Databases - can be protected by copyright law}

Databases as a whole (either in printed or digital format) can be protected by copyright if they fulfil the criteria that they are original in the selection and arrangement of content. For example copyright protection may not apply to a simple alphabetical listing, but may apply to an original compilation containing numerous categories of information such as the UK Stock Exchange listing or the UK "Yellow Pages" supplier contacts directory as these manifest an "intellectual creation". It is also the case that any original contents such as essays or pictures within a database are protected by copyright even though they are in digital format. Finally, it is the case that the usual statutory copying exceptions are still permitted (though copying from databases by librarians in prescribed libraries is not permitted). However the originality of databases as a whole is very difficult to prove legally for makers of databases and since a 1997 Statutory Instrument came into force, they have increasingly tried to rely on the lower form of proof contained in a new legal right called "database right" to protect their intellectual property and investment.

\footnotetext{
${ }^{8}$ See www.opsi.gov.uk/advice/crown-copyright/index.htm

${ }^{9}$ See www.opsi.gov.uk/advice/parliamentary-copyright/index.htm
} 


\section{Databases - can also protected by "database right"}

The Copyright and Rights in Databases Regulations, 1997 (SI 1997/3032) created a sui generis property right called "database right". This gives database makers the legal right to prevent unauthorised extraction and / or re-utilization of the contents of a database where there has been a substantial investment in the obtaining, verifying and presenting of the database contents. Since the regulations became law there has been some litigation in the national courts and at the European Court of Justice as to the precise meaning of this sui generic right. In its most recent judgements, it seems that the ECJ has significantly narrowed this right by ruling that "creating" data is not the same as "obtaining" data for these purposes. ${ }^{10}$ It decided that under these regulations, "obtaining" only occurs when the database maker researches, seeks out and collects pre-existing independent materials and collates them into a database. It does not occur where lists or databases are simply created. Consequently it can be said that currently "database right" does not usually protect annual fixture lists of sporting organisations where it can be argued that the data has been created rather than obtained. The duration of this legal protection is set at 15 years after the end of the calendar year in which the database was made. If the database is made available to the public within the 15 year period, the term of the database right will expire 15 years after it has been made public. It can be argued, however, that legal protection might be indefinite or "rolling" as many database makers invest substantially in their databases and update their contents on a regular basis.

The $1997 \mathrm{SI}$ also gave lawful users of a database limited statutory permissions to copy by allowing them the legal options to either:

a) Extract but not re-utilize a "substantial" part of a database that has been made available to the public, if the extraction is for the purpose of illustration for teaching or research and not for any commercial purpose, or

b) Extract and re-utilize "insubstantial" parts of a database that has been made available to the public (where re-utilisation means making the contents of a database available to the public by any means). Lawful users should bear in mind that repeated or systematic extraction and re-utilization of insubstantial parts could amount to a substantial part and become an infringement of database right.

Statutory permissions to copy were also given for copying for parliamentary and judicial proceedings and for the purposes of helping some public administration (e.g. copying for the purposes of a Royal Commission or a statutory inquiry). However, there was no specific library copying permission.

\section{New right for owners of digital material from SI 2003/2498}

The UK Statutory Instrument 2003/2498, which we mentioned earlier in relation to the restriction of the fair dealing exception to non-commercial use, also introduced a new controversial right for owners of digital material. ${ }^{11}$ In a nutshell the 2003 SI stated that if a digital technological protection device (such as a password or an encryption device) is used by a database maker to prevent access or copying from their free website, for example, then this device may not be circumvented for unlawful purposes. However the problem for users is that if a person wishes to make a copy for a lawful purpose under one of the statutory copying exceptions I mentioned earlier

\footnotetext{
${ }^{10}$ ECJ case: C-203/02 The British Horseracing Board Ltd v William Hill Organisation Ltd Decision of the ECJ, November 9, 2004.

${ }^{11}$ Copyright and Related Rights Regulations, 2003 (SI 2003/2498).
} 
(e.g. a fair dealing copy for non-commercial research or private study purposes or a copy for judicial proceedings or a copy in an accessible format such as Braille for a visually impaired person), how can a copy be made if the technological protection device blocks any copying at all? This concern about protection devices blocking lawful copying under one of the few statutory exceptions was raised in Brussels during the adoption process of the 2001 EU Copyright Directive and a compromise was included in the Directive which allowed national governments to include safeguards in their national implementing legislation. The UK solution contained in the $2003 \mathrm{SI}$ is potentially both cumbersome and inadequate for users who want to make a lawful copy. Although the detailed procedures are still to be published by the UK Intellectual Property Office, it is intended that the user should be allowed to complain by issuing a "notice of complaint" to the Secretary of State at the Department of Trade and Industry (now called the Department for Innovation, Universities and Skills), who can name and shame the offender if they find in favour of the complainant. However, the Secretary of State can only issue a direction to the rights owner to ensure that the permitted act can occur. If the rights owner ignores this direction, it will be for the complainant to take action via the courts for breach of statutory duty. This would be a risky, time-consuming and expensive process that is not satisfactory for users and indeed is likely to discourage complaints from individuals. This whole issue, and how it can be resolved, is very much a copyright concern at present for librarians and their users.

Furthermore, it should be pointed out that even this cumbersome legal solution does not apply if there is a voluntary licence scheme or legally binding contract already in place. For example, the possible legal route to the Secretary of State would not apply if the digital works were locked-up behind a technological protection device in a licensed or contractual subscription database. In these cases, contract law will ${ }^{12}$ almost certainly over-ride copyright law and users would not be able to claim lawful access under one of the statutory copying exceptions.

\section{Other legal ways to obtain authorisation to copy}

If one wants to copy more than is permitted by the statutory exceptions, what are the options for staying legal? Firstly one can try to negotiate permission (and probably a fee) directly with the individual rights-owner, although this is usually time-consuming and it may not be possible in practice to locate or determine the current rights-owner. Secondly, one can simply pay for an individual or sector licence from a publisher or a licensing agency such as the Copyright Licensing Agency (CLA) or Newspaper Licensing Agency (NLA). For example the CLA offers a Library Sticker Scheme which allows walk-in users at libraries to make copies for commercial purposes upon payment of a fee (currently £9) to the librarian for passing on to the CLA. Also the commercial document supply services run by the Institute of Advanced Legal Studies Library, the Law Society of England and Wales Library and the Bodleian Law Library are able to operate as they have taken out CLA transactional document delivery licences. ${ }^{12}$ These type of licences are usually fairly quick to arrange but often costly as individual libraries will have very little leverage with the large publishers and national licensing agencies and will usually have to accept what they are offered,

\footnotetext{
${ }^{12}$ For more details about the role and types of licences offered by these national agencies see www.cla.co.uk and www.nla.co.uk. See the following library websites for details of their commercial document supply services: http://ials.sas.ac.uk/; www.library.lawsociety.org.uk; http://www.ouls.ox.ac.uk/law.
} 
such as "shrink-wrap" or "click-use" digital licenses which give no rights of access for copying under the statutory copying exceptions.

If possible, it makes sense to try to join up with other like-minded libraries to form a consortium. A good example of this in the UK is "JISC" or the Joint Information Systems Committee which negotiates with publishers on behalf of the UK Higher Education Funding Council for England (HEFCE) to obtain beneficial licensing deals for UK higher education libraries. ${ }^{13}$ Many librarians see consortia licences as a partial answer to the might of the publishers and national agencies. Other partial solutions are the growth of "open-access" or "open-source" material and the increasing use by individual authors of "Creative Commons" licences. Open source material is a digital version of scholarly material that is freely available either in an institution's electronic repository or in open access journals that do not levy a subscription charge to users. ${ }^{14}$ Creative Commons is an international non-profit making organisation that offers a flexible range of copyright licences from which authors can pick the most appropriate for themselves. Rather than using the traditional "all rights reserved" copyright licence, authors such as academics can choose a "some rights reserved" Creative Commons licence that will retain their copyright while at the same time widening the access and copying of their works for educational reasons. ${ }^{15}$ Also it should not be forgotten that many governments make much of their legislative material freely available to the public for access and copying on a "copyright-waived" basis.

\section{Some suggested solutions to the digital copyright concerns of librarians}

Having surveyed the current copyright regime here in the UK, I would now like to discuss the highlighted worries of librarians and information professionals concerning a number of outstanding digital copyright issues and suggest some possible solutions. An important point is that there are very similar digital copyright concerns in other jurisdictions such as Australia, Canada, Denmark, France and the USA. Through their separate national library associations' information professionals have been helping each other to lobby national governments strongly on similar solutions to these issues so that a better "copyright balance" is achieved.

\section{1) Technological protection devices}

I have already discussed that librarians and information professionals are very concerned that technological protection devices such as passwords are blocking lawful access and copying of digital works under the statutory exceptions. In April 2006, the Libraries and Archives Copyright Alliance (LACA) and the Museums Copyright Group (MCG) put forward joint solutions to government. ${ }^{16}$ LACA and MCG propose that the law should be specifically amended to allow circumvention of technological protection devices in cases where the device obstructs access or copying by a user who wants to exploit a statutory exception to copyright (or database right, if applicable). This change in the law would prevent users having to struggle through the proposed complex, time-consuming and expensive Secretary of State procedures to obtain permission. Instead a simple system of legitimate users approaching publishers directly and requesting the password or decryption device could be introduced. It is also proposed that the UK Copyright Tribunal could

\footnotetext{
${ }^{13}$ For more details about this consortium see www.jisc.ac.uk.

${ }^{14}$ A useful web directory of many open access journals is available at: www.doaj.org.

${ }^{15}$ See www.creativecommons.org.uk.

${ }^{16}$ LACA/MCG Joint Proposals to the UK Government for the Revisions to the Copyright Designs and Patents Act 1988. April 2006. pp.7-11. Full document published at: http://www.cilip.org.uk/policyadvocacy/copyright/lobbying/laca1.htm.
} 
"become the appeal authority with enforceable judgments and also for it to provide a very swift 'small claims' procedure to deal with complaints". ${ }^{17}$

\section{2) "Shrink-wrap" or "click-use" licences}

Similarly, LACA and MCG propose a specific change in the law to overcome the problem of "shrink-wrap" and "click-use" digital licenses preventing legitimate access and copying of digital material under a statutory exception to copyright or database right. The change in the law is needed in these cases as it is thought that currently contract law overrides copyright law in almost all circumstances. It is proposed therefore that non-negotiable contracts and licenses should not be allowed to override the statutory copyright and database right exceptions. In effect any clauses in these type of contract that restricts or removes the statutory exceptions would become legally null and void.

\section{3) Problem of "orphan" copyright works}

Librarians and information professionals often seek to republish or digitalise works for research or preservation purposes or as part of a digitalisation project. However "orphan" works (i.e. works that are still protected by copyright but whose rights owners are either very difficult or impossible to trace after reasonable enquiry) can cause huge problems and expense for gaining rights clearances. In a new statement on orphan works published in December 2007, LACA proposes three potential solutions to this growing problem, each of which seek to balance the interests of the rights owners with the need to protect users and libraries who want to make material accessible via digitalisation without risking punitive damages if the rights owners subsequently makes themselves known. Their three solutions, and the circumstances where these would be most applicable, are as follows:

i) The "licensing solution": where legislation is passed which enables users to take out a licence from an appropriate body (such as the CLA) which provides an indemnity against litigation if the rights owners subsequently make themselves known. The licence fee would be passed to the rights owner if they subsequently appeared within a statutory period. Otherwise the fee could be returned to the user or used for relevant charitable purposes. This solution would be most applicable to published literary works and some artistic works;

ii) The "diligent search solution": where a new statutory permission exception is enacted which allows users to use orphan works without specific permission as long as there has been diligent enquiries made to identify and locate the copyright owner (the word diligent would need to be legally defined). The legislation would need to make clear the rights of the copyright owner, should he or she then come forward, and what would be the remuneration from the user. In these circumstances rights owners should not be able to claim damages from the users. This solution would be most applicable to works where licensing is not an option such as unpublished literary material; and

iii) The "mass digitalisation solution": where a new statutory permission exception is enacted which allows "not for profit" educational, cultural and research institutions working with a large number of orphan works to use them without specific permission as long as notices are published inviting rights owners to come forward, existing sources of rights owners are

\footnotetext{
${ }^{17}$ LACA/MCG Joint Proposals to the UK Government for the Revisions to the Copyright Designs and Patents Act 1988. April 2006. p.11.
} 
checked and these institutions are willing "to pay appropriate fees for continued use on the basis of the fees that would have been payable had prior permission been obtained." 18 In these circumstances rights owners should not be able to claim damages from the users.

LACA also proposes the establishment of a free publicly available voluntary register of rights owners to help minimise the problems presented by orphan works (the introduction of a statutory compulsory register of copyright works and their owners would be in contravention of the UK's obligations under the Berne Convention). The French society of authors is also investigating the idea of a voluntary register of deceased rights owners and French user communities are seeking legislation which will have the affect of indemnifying libraries and users if the deceased author is not on the register. ${ }^{19}$ Something may well be done by the UK government on this issue in the near future as three key recommendations of the influential 2006 report of the independent Gowers Review of Intellectual Property were that:

1) a provision in respect of orphan works should be proposed by the UK Government to the European Commission which would have the affect of amending EU Directive 2001/29/EC;

2) the UK Patent Office (now the UK Intellectual Property Office or IPO), in consultation with rights-owners and collecting societies, should issue clear guidance on the parameters of a "reasonable search" for orphan works; and

3) the UK IPO should set up a voluntary register by 2008 , either on its own or in collaboration with database owners. ${ }^{20}$

\section{4) Digital copies of copyright-protected works in library collections} LACA and MCG are also concerned that by the time copyright and database right expires in a work the rights owner may have gone out of business or after many company mergers it will prove impossible to trace the current rights owner. This is a problem for users and librarians, as at this point they will require the passwords or keys to the encryption devices from the rights owner to provide free and uninhibited access to the now out-of-print works. However, if the rights owner is not traceable (or if it is expensive or cumbersome to make such a search) how will the public gain access to these works? It is also a worry that even if the rights owner is traceable, they might not have bothered to upgrade their digital works to other formats in order to preserve them and make their content fully accessible and usable once out of copyright. LACA and MCG therefore propose that UK prescribed libraries, as "custodians of the human memory", should be allowed to circumvent technological protection devices now as trusted third parties in order to make digital copies of material in their permanent collections for preservation purposes and in order to migrate the content into new useable formats. Prescribed libraries can then provide reliable public access once the copyright and database right expires in a digital work.

\footnotetext{
${ }^{18}$ LACA Statement on Orphan Works, December 2007. p.2. Full document published at: http://www.cilip.org.uk/policyadvocacy/copyright.

${ }^{19}$ LACA/MCG Joint Proposals to the UK Government for the Revisions to the Copyright Designs and Patents Act 1988. April 2006. p.23.

${ }^{20}$ Recommendations $13,14 \mathrm{a}$, and $14 \mathrm{~b}$ of the final report of the Gowers Review of Intellectual Property (2006) HM Treasury at: www.hm-

treasury.gov.uk/independent_reviews/gowers_review_intellectual_property/gowersreview_ind ex.cfm.
} 
Finally, in order to provide continuing protection for users, LACA and MCG propose that the UK government, through the good offices of the UK Intellectual Property Office, regularly reviews the adverse affect of technological protection devices on preventing lawful access and copying under the statutory exceptions. LACA and MCG also suggest that the ongoing review should monitor the problems posed by out-of-copyright works being unavailable for public use because the rights owners are untraceable (and the passwords or encryption devices are lost) or the works themselves have not been properly migrated to new useable formats.

\section{Cautious optimism}

Although it remains to be seen whether the current UK government will be minded to support all the major changes to UK copyright legislation that librarians are lobbying for both in this country and in other jurisdictions, there are some early indications in 2008 that the current UK government may be starting to listen. Recently a government consultation paper entitled, "Taking forward the Gowers Review of Intellectual Property - proposed changes to copyright exceptions" was launched by Lord Triesman, Minister for Intellectual Property. ${ }^{21}$ This consultation paper considers how best to take forward the 2006 Gowers Report and make changes to UK copyright law exceptions which would have the affect of "modifying copyright rules to improve access to, and use of, copyright material for private individuals, students and libraries." ${ }^{22}$ Among the recommendations, the consultation paper considers how best:

1. to help universities facilitate distance learning courses via interactive whiteboards and VLE's; and

2. to allow libraries and archives to use technology to preserve works before they deteriorate or the format in which it is stored becomes obsolete.

These are, of course, just preliminary government recommendations, complete with options, within a consultation paper, but at least they indicate that the debate over some of the outstanding digital copyright issues raised in this article is continuing, if only in a limited way so far. We shall await with interest to see the affect of pubic consultation on these preliminary recommendations and thereafter the details of any final changes to UK copyright law before making any firm conclusions. It seems that the current UK government may be starting to listen to the arguments of librarians and information professionals but many of the major digital copyright concerns have still to be addressed, much less resolved.

\section{Conclusions}

In the course of this overview I hope I have shown that, although over twenty years old, the Copyright, Designs and Patents Act of 1988 is still one of the most important and influential pieces of UK copyright legislation. It is also the case that key Statutory Instruments concerning digital material and databases have significantly altered the scope of the 1988 Act as successive governments have tried to keep pace with fast moving technological developments and to maintain the "copyright balance" between protecting the legitimate economic and moral rights of rights owners on the one hand and providing fair levels of access and copying for librarians and researchers on the

\footnotetext{
${ }^{21}$ The press release, consultation paper and detailed recommendations can be viewed via the UK Intellectual Property Office website at www.ipo.gov.uk.

${ }_{22}$ UK Intellectual Property Office, Taking forward the Gowers Review of Intellectual Property. p.1 (Forward by Lord Triesman).
} 
other. Nevertheless, for many librarians and information professionals there are still a number of outstanding digital copyright concerns to be addressed before this "copyright balance" is finally achieved. The welcome but limited recent government consultation paper on taking forward UK copyright law in the wake of the recommendations of the 2006 report of the Gowers Review of Intellectual Property gives librarians and information professionals some grounds for cautious optimism that more major changes might be coming, but we are still at the beginning of the reform process and librarians and information professionals will need to keep up the lobbying pressure on the government. 


\section{Bibliography: current UK copyright law}

Books

Aplin, T. Copyright law in the digital society: the challenges of multimedia. Hart Publishing, 2005.

Bently, L. and Sherman, B. Intellectual Property. $2^{\text {nd }}$ ed., Oxford University Press, 2004.

Copinger and Skone James on Copyright. 15 ${ }^{\text {th }}$ ed., Sweet \& Maxwell, 2005.

Cornish, G. Copyright: interpreting the law for libraries, archives and information services. $4^{\text {th }}$ ed., Facet Publishing, 2004.

Cornish, W.R. and Llewelyn, D. Intellectual Property: Patents, Copyright, Trade Marks and Allied Rights. $5^{\text {th }}$ ed., Thomson, Sweet \& Maxwell, 2003.

Norman, S. Practical copyright for information professionals. Facet Publishing, 2004.

Pedley, P. Digital copyright. $2^{\text {nd }}$ ed., Facet Publishing, 2007.

Pedley, P. Essential law for information professionals. Facet Publishing, 2003.

Sterling, J.A.L. World Copyright Law. $2^{\text {nd }}$ ed., Sweet \& Maxwell, 2003.

Stokes, S. Digital copyright: law and practice. $2^{\text {nd }}$ ed., Hart Publishing, 2005.

$\underline{\text { Useful web links }}$

British Library copyright FAQ's advice:

http://www.bl.uk/services/information/copyrightfaq.html

Copyright Licensing Agency (CLA): www.cla.co.uk

Creative Commons Licenses: www.creativecommons.org

For Crown and Parliamentary copyright see the website of the Office of Public Sector Information:

www.opsi.gov.uk/advice/crown-copyright/index.htm or

www.opsi.gov.uk/advice/parliamentary-copyright/index.htm

Gowers Review of Intellectual Property (2006) HM Treasury at: www.hmtreasury.gov.uk/independent_reviews/gowers_review_intellectual_property/gowersre view_index.cfm.

Libraries and Archives Copyright Alliance (LACA): $\underline{\text { www.cilip.org.uk/laca }}$

Newspaper Licensing Agency (NLA): www.nla.co.uk

Sherpa (help with rights clearances for e-repositories): http://www.sherpa.ac.uk/

UK Intellectual Property Office or the IPO (formerly called the UK Patent Office) is an Executive Agency of the Department of Innovation, Universities and Skills: www.ipo.gov.uk 